\title{
A LITERATURA COMO UM ESPAÇO SOLIDÁRIO: O PÚBLICO E O PRIVADO NA OBRA DE FERNANDES BARBOSA (1910-1988) ${ }^{1}$
}

\section{LITERATURE AS A SOLIDARY SPACE: THE PUBLIC AND THE PRIVATE IN THE WORK OF FERNANDES BARBOSA (1910-1988)}

Ellen dos Santos Oliveira*

Resumo: Este trabalho traz questões sobre o processo de criação e publicação das obras de Nilo Fernandes Barbosa (1910-1988), que nos leva à reflexão sobre as dificuldades de criação e publicação no séc. XX, e como o espaço literário acaba sendo um ato de solidariedade. Refletindo ainda, sobre os aspectos públicos e privados das e nas obras do autor gaúcho. Durante a pesquisa trabalhamos com os manuscritos e os datiloscritos do autor, além de arquivos históricos disponíveis no Museu de Cachoeira do Sul-RS. Pretende-se, assim, contribuir com a crítica literária no Brasil e, também, com a fortuna crítica do autor.

Palavras-chaves: Espaço literário. Fernandes Barbosa (1910-1988). Público e privado.

AвSTRACT: This work raises questions about the process of creation and publication of the works of Nilo Fernandes Barbosa (1910-1988), which leads us to the reflection on the difficulties of creation and publication in the century. XX, and how literary space ends up being an act of solidarity. Also reflecting on the public and private aspects of and in the works of the gaucho author. During the research we worked with the author 's manuscripts and typewriters, as well as historical archives available at the Cachoeira do Sul Museum - RS. It is intended, therefore, to contribute to literary criticism in Brazil and, also, to the writer's critical fortune.

KeYwords: Literary space; Fernandes Barbosa (1910-1988); Public and private.

${ }^{1}$ O presente trabalho foi realizado com apoio da Coordenação de Aperfeiçoamento de Pessoal de Nível Superior - Brasil (CAPES) - Código de Financiamento oo1.

"Doutoranda em Letras pela Universidade Federal de Sergipe (UFS). Email: profa.ellen.oliveira@live.com. Orcid: https://orcid.org/0000-0002-4728-5766. 


\section{INTRODUÇÃO}

A literatura é, antes de tudo, um espaço de ficção, de criação, como afirmou Maurice Blanchot (2011), ao falar sobre "O espaço literário" em que ele o situa como um espaço de despoder, onde a linguagem não é um poder pois o que se afirma nela acaba se negando por se tratar de ficção. Ou seja, o espaço em que a linguagem literária se realiza é de natureza ficcional, diferente da linguagem jornalística, jurídica, historiográfica, etc. Embora ela possa compartilhar elementos semelhantes dessas outras manifestações da linguagem, principalmente quando chegam a cruzar por esses espaços que o autor acaba cruzando durante sua jornada humana existencial e suas práticas de linguagem, entre elas a literária. Como veremos mais adiante, no caso de Nilo Fernandes Barbosa, que além de escritor, poeta, cronista e contista, foi também repórter, atuou como advogado, e, enquanto servidor público, escreveu e proferiu discursos em atos políticos de Cachoeira do Sul-RS. E essa transição do autor possibilitou a criação de um espaço identitário e solidário não apenas consigo mesmo, mas com o outro e os outros espaços.

Em relação à linguagem, entenderemos o espaço literário numa perspectiva culturalista, que como explica Brandão (2007), trata-se da retomada da noção de literatura como representação, isto é, revalorizando a perspectiva mimética que havia sido deixada um pouco de lado pelos estruturalistas. Assim, a literatura serve apenas como objeto de análise da sociedade, sem se sobrepor a outras formas discursivas da sociedade, mas acaba sendo mais uma configuração cultural em que a linguagem literária se manifesta (BRANDÂO, 2007, p. 30).

Em relação à recepção que faremos dessas manifestações literárias do poeta, além de considerar os espaços público e privado em que foram publicadas, como o jornal e o livro, entenderemos como imaginário espacial numa perspectiva determinista e com fatores socioculturais. Reconhecendo, assim como Brandão (2007) o embate que há entre o legado romântico-idealista, que advoga a autonomia da obra de arte, cuja negatividade se manifesta no universo das formas, e, também, o legado realista-positivista, que concede a obra como reflexo do mundo, devido aos conteúdos sociais que ele veicula. Assim sendo, também entenderemos o espaço como um sistema cultural-formal de um "horizonte de expectativas" que, de certa forma, acabam definindo os significados espaciais (BRANDÃO, 2007, p. 32).

Nilo Fernandes Barbosa (1910-1988), ao adentrar nesse espaço literário, determinado por fatores sócios culturais, acaba se desdobrando em dois "eus - fictícios", dois pseudônimos, Fernandes Barbosa e João do Adro, que acabam sendo determinados e identificados pela transição humano existencial do autor em contato com os espaços reais. Em sua obra temos exemplos do exercício da solidariedade entre espaços reais/fictícios, público/privado, o eu/ o outro, etc. Em seu poema "solidariedade", embora assine como João do Adro, o eu lírico revela e localiza cada um de seus pseudônimos de forma neutra, mostrando onde residem, a marca ideológica de cada um, e a motivação para atuar nesse espaço imaginário do fazer literário: 
"O Fernandes girondino / E João do Adro jacobino, / Moram juntos, num galpão... / Basta um ser ofendido, / Para que os dois, sem partido, /Ergam a luva do chão!” (JOÃO DO ADRO. In. FERNANDES BARBOSA, 1968).

Nesse poema, o eu-lírico revela que ambos os pseudônimos "moram juntos num galpão...", ou seja, ambos são personagens fictícios, dotados de ideologias distintas, e que moram nesse espaço literário imaginário criado pelo poeta ao qual ele chama de "galpão". Trata-se de um espaço solidário, pois ambos os personagens são capazes de ceder às próprias ideologias para agirem em defesa do outro. Ou seja, pelo bem comum ambos erguem "a luva do chão". Tal expressão "erguer a luva do chão" pode ser entendida como o ato de criação. Nesse caso, luva no sentido básico de dicionário significa "peça do vestuário que se adapta ao formato das mãos e dos dedos, utilizada contra o frio, como proteção ou como adorno" (LARROUSE, 2001, p. 615).

Há um espaço amplo, o "Galpão", que podemos interpretar como o inconsciente do poeta, o Nilo Fernandes Barbosa, o poeta, autor, escritor - uma vez que ele escreveu não só poesias, mas também, contos, crônicas, reportagens, discursos políticos. Nesse espaço reside o Fernandes Barbosa e o João do Adro, ambos considerados como "eu-fictícios" do poeta, que ora assume-se como um, oura como o outro. Acontece que, nesse espaço, seu mundo interior, seu “Galpão" é onde ele se recolhe para refletir sobre o próprio fazer literário, sobre sua condição humano-existencial, sobre sua ação e reação no mundo exterior. A literatura acaba sendo essa projeção do seu mundo interior agindo em seu mundo exterior, que se reflete em vários espaços secundários. Assim, cada obra, cada criação, configura-se como uma experimentação em um ambiente criado a partir de uma realidade vivenciada ou imaginada pelo autor. Daí, encontramo-nos nos múltiplos espaços que somos convidados a visitar em suas obras.

Em relação ao processo de publicação da obra poética, focando nos poemas líricos e épicos, consideremos dois espaços: há um espaço de caráter mais público, o jornal, onde ele publicou seus poemas como João do Adro, e o espaço de caráter mais privado, o livro, onde ele se assume como Fernandes Barbosa. Porém tal consideração deve ser apenas para uma tentativa de organização das ideias e uma forma de compreender a produção lírica do autor. Primeiro, porque tanto o jornal como o livro, têm seu caráter público e privado. Segundo, porque no Jornal ele publicou crônicas e reportagens assumindo-se Fernandes Barbosa. E terceiro, porque muitos de seus poemas publicados em jornais como João do Adro, posteriormente foram reunidos e publicados em um livro que ele assinou como Fernandes Barbosa. Enfim, apesar de todas essas questões, que devemos ter em mente para não cair em generalizações sobre a produção poética do autor, temos em vista que, a princípio a pesquisa foca apenas na poesia lírica e épica, levando em conta o contexto em que foram publicadas, tal definição serve para compreender, e talvez, definir a gene literária do autor, e conseguir interpretar seu desdobramento nesses dois "eu-fictícios", tendo em vista que ambos apesar de características peculiares, mais em alguns aspectos, semelhantes, funcionam como "uma crase fundamental e manejam a mesma pena”, conforme afirmou o próprio autor em entrevista ao Jornal do Povo. 
Assim, tentaremos não esquecer que mesmo no espaço público, há o privado, e no espaço privado, há o público. Trata-se de um diálogo universal da condição humana, em que o mundo interior conectado com o mundo exterior, e desse contato temos a relação quase indissociável da fiç̧ão com a realidade. Para compreender melhor a atuação do autor, passaremos, a princípio, à análise de seu comportamento e suas manifestações nesses espaços, público e privado, desde à definição básica do que seria cada um até uma breve análise do que foi produzido e publicado nesses, para e sobre esses espaços. E em seguida, faremos uma análise sobre o espaço como ficção, focando mais nas manifestações espaciais projetadas no inconsciente do poeta e materializadas em seus poemas.

\section{Espaço Púbuico}

Quando falamos em espaço público, nos referimos tanto a um sentido adjetivo, que diz respeito à manifestação individual do autor, em seus espaços sociais, ou mesmo quando nos referimos ao sujeito. Consideramos também que o próprio Fernandes Barbosa se assume como duplo: por um lado, o Girondino, aquele que representa a classe trabalhadora e tem mais domínio nas estruturas sociais, políticas e culturais; e por outro lado ele caracteriza o João do Adro como Jacobino, idealizando-o como aquele que representa o povo, mas que luta para fazer parte dessas estruturas.

Apesar da caracterização, tal como concebe o autor, e ainda que ambos sejam dois, configuram-se como um só. Ou seja, no projeto literário do autor, o trabalhador é o povo, e o povo é trabalhador. Uma vez que os dois são ele, o Nilo Fernandes Barbosa, e ele é os dois, mesmo quando se assume um, a face do outro está oculta, e vice-versa. Trata-se de um poeta híbrido e multifacetado, e, sendo assim, a face do João do Adro acaba sendo talvez uma máscara social ou uma projeção mais distante de um "eu" que, quando o assume, o faz para proteger e preservar mais a sua imagem mais próxima do que acreditam ser seu "eu real", inclusive o próprio nome Fernandes Barbosa é um sobrenome composto da família do autor, que segundo a filha Ana Rita são indissociáveis.

Assim sendo, tomemos a definição de público pelo seu emprego seja de forma adjetivada ou individualizada. Em relação ao sujeito: "O povo em geral. Número determinado de pessoas reunidas em torno de um interesse em comum” (LARROUSE, 2001, p. 813). Entendendo dessa forma, podemos dizer que quando o autor se assume como João do Adro, ele o faz com o aparente objetivo de aproximar o texto do povo, sem deixar de excluir o próprio eu. Já quando assume como Fernandes Barbosa, ele o faz para aproximar o texto do contexto privado, particular do autor, mesmo que para esse espaço ele acabe levando experiências coletivas experimentadas não só no espaço privado, mas público, também.

Tomando o sentido público como adjetivo, estamos dizendo que se trata de algo, textos, obras, ideias, etc., ou seja, relativo ou pertencente a um povo, uma coletividade, manifesto, 
conhecido por todos. E que é aberto a quaisquer pessoas. Pode ser os poderes públicos, os três poderes do Estado estabelecidos pela constituição. E/ou, o direito público, conjunto de leis que regulam os interesses de ordem coletiva (LARROUSE, 2001, p. 813).

Independente de Jornal ou Livro, ambas publicações pertencem a um povo, a uma coletividade. Porém, no contexto em que foram escritas, os poemas publicados em jornais acabam tendo maior visibilidade, pois estava ao alcance de um público maior que os livros, cujas tiragens não passavam de cem exemplares e eram distribuídas a uma parcela selecionada de leitores, geralmente amigos e conhecidos, tanto em Cachoeira do Sul - RS, como em outros lugares do país, ou fora.

Sua produção literária, jornalística e política - pois apesar de não ter assumido funções políticas, como secretário estadual em diversos governos, acabou escrevendo discursos políticos - não só traduzem o espaço local, mas dá um panorama nacional do Brasil, e muitas dessas obras, principalmente a literária, acabam revelando o humano em sentido e espaço universais. Por mais que o autor tente se auto preservar, e/ou talvez por isso mesmo, acaba por não poupar nem as si mesmo, quando escreve, e nem aos outros. Sua literatura é manifesto e manifesta sua experiência pública e privada. De um lado, tomando para si o conhecimento, o desejo, os anseios e dores do povo. De outro, compartilhando com o povo, o fruto de seu trabalho, aquilo que ele tem a oferecer de si, e que não quer apenas para si. Temos assim um espaço público, pois é compartilhado por todos, inclusive pelo poeta e, também, para ele. E um privado que acaba sendo, de alguma forma, também público.

Em relação aos poderes públicos, o fato de o autor transitar por esses poderes seja no âmbito político - poder legislativo, executivo e judiciário - seja no âmbito literário - que seria poderes relacionados ao próprio fazer literário, suas leis e especificidades de cada gênero suas obras acabam estabelecendo diálogos entre os dois campos. Em algumas obras, em que ele exerce a metalinguagem, esse diálogo está explícito. Seja em poemas assinados como João do Adro em que ele satiriza alguns representantes do povo nesses espaços de poder. Entre vários poemas escritos nesse estilo e assinado por João do Adro, cito, por exemplo "Olimpíada Política”, em que o autor satiriza a atitude de um político por "cambiar de partido", atitude que aos olhos do "eu-lírico" que se assume pelo povo, parece desagradável e reprovada, conforme lê-se abaixo:

Que sórdido papel o de Sarney, / Cambiando de Partido, abrutamente, / Papel inominável que gravei / No rol do que se tacha de indecente. / Há bem pouco, era o chefe de uma grei, / O cacique, o tuxava, o presidente, / Que no Senado, defendendo a Lei, / Os êmulos o tinham pela frente. / Mas, agora, depois da luta insana / Da macacada, por maior banana, / Ao pódio sobe o olímpico trânsfuga! / Pois se bandeou com armas e bagagem, / Para ser a segunda personagem, / Que a oposição, contra o Maluf, aluga. (JOÃO DO ADRO. In. JORNAL DO POVO, ?) 
Como podemos observar claramente, o poema faz pensar tanto na atuação do eu-lírico no uso das leis literárias, e no episódio envolvendo o personagem inspirado em um sujeito público, inclusive citado no poema, o Sarney, fazendo um elogio por outrora agir em defesa da Lei mas, em seguida, faz duras sátiras por sua mudança de posição partidária, no âmbito da política brasileira da época.

No soneto acima o João do Adro, o "eu-fictício" que representa o povo, aparentemente de forma até bem ousada e destemida, domina quase perfeitamente a linguagem e a estrutura literária, com apenas um erro ortográfico em "abrutamente" e uma diferença na métrica quase todos os versos são decassílabos, com exceção do segundo verso da segunda estrofe, em que temos doze sílabas poéticas, e o terceiro verso da terceira estrofe, com onze sílabas. Se tais erros ou incidências que os poemas revelam aos leitores e críticos mais atentos foram feitos intencionais ou não, isso não parece ser motivo para diminuir o povo e exaltar o trabalhador mais intelectual representado pelo Fernandes Barbosa, uma vez que esse, em alguns casos, apresentam alguns erros de digitação, que são corrigidos manualmente.

Essas ocorrências fazem refletir sobre a atuação desses dois tipos de intelectuais, aquele que emerge do povo e deseja dominar as estruturas, e aquele que domina as estruturas e é solidário com o povo. Afinal, a própria ideia de perfeição é algo questionável, assim como a noção de erro, conforme afirma o autor, em uma de suas trovas manuscritas, e assinadas por João do Adro: "Eu sou cheio de defeito... / - Defeito quem não os tem? - / Defeitos, não! - São preceitos, / Da arte de viver bem!" (JOÃO DO ADRO. In. FERNANDES BARBOSA, 1968).

A quadra, escrita em sete sílabas poéticas, revelam com perfeição a humildade do poeta de não ter essa pretensão em ser perfeito, mas de buscar uma "arte de viver bem". O poema assinado como João do Adro, parece um elogio a esse estilo de intelectual do povo que luta e se esforça para ocupar os espaços de poder. Como grande incentivador da educação, das artes e da cultura que foi enquanto homem público da cidade, Nilo Fernandes Barbosa tentou contribuir com a formação intelectual de seu povo, tentativa que lhe rendeu inclusive prêmio e grandes admiradores intelectuais de seu tempo.

Evidente que é difícil definir de forma a separar o que venha ser espaço público e privado quando se trata de uma escrita em que o próprio autor já se assume como uma "crase". Tal dificuldade é revelada, inclusive, pelo próprio autor, quando em seu poema "Plágio", conforme cito:

Quem escreve e conserva, avaramente, / Inédito o poema que escreveu, / É porque não quer repartir com a gente, / O que, de fato, sabe ser só seu. / Porém, se ao publicar, está patente, / Que a sua jóia ao povo ofereceu, / E que não pode jamais, daí pra frente / Reivindicar o mimo que ele deu. / Eu fico imensamente satisfeito, / Quando sei que o meu verso-girassol, / Alguém o toma por amor-perfeito. / E diz que o amor 
perfeito é todo seu / Enquanto, com prazer risco do rol, / O heliotrópio que um dia foi só meu.

(JOÃO DO ADRO, In: JORNAL DO POVO, 1934)

Temos no poema acima, um exemplo que serve, inclusive, como uma sútil ironia, pois o poeta acaba denunciando como exemplo uma prática de plágio de si mesmo. Pois o estilo metalinguístico utilizado no poema é uma característica marcante do Fernandes Barbosa, que escreveu vários poemas que refletem sobre o próprio fazer poético. De um lado, isso revela que o "eu-lírico" que representa o povo recorre, em alguns casos, a essa prática que contraria as próprias leis e os princípios autorais, mas por se configurar "um plágio autorizado" pois parece ter sido oferecido ao povo, parece ser visto como uma atitude solidária. Claro que estamos falando de um plágio de um "eu-fictício", ou seja, de um pseudônimo com o autor, e por isso torna-se uma "brincadeira”, ou exemplo de uma representação comportamental no espaço ficcional.

Ainda sobre os possíveis erros cometidos nesse espaço literário, no poema "O Revisor e o Escriba", Fernandes Barbosa, o "eu-fictício" todo trabalhado na educação, na cultura e conhecedor dar artes em geral, vem a público se defender e acusar o revisor do Jornal de alterar de forma abusiva seus textos. Errar, ou ser acusado de erro, é comum seja nos espaços públicos ou privados, literários ou não. Na biografia e bibliografia de Nilo Fernandes Barbosa, quando esse incidente por ventura viesse acontecer ele poderia contar com o "eu - fictício" que se assumia como advogado do povo não só na realidade, quando usava seus poemas para agir em defesa de algum cliente - como no poema "O prefeito e os ovos", que ele fez em defesa de um feirante e publicou no jornal como "Fernandes Barbosa, recebendo suspensão por um mês e sem vencimentos, e respondendo com outro poema "Sargento, Capitão e Prefeito", em que ridiculariza, sem dó, o prefeito da cidade, inclusive chamando-o de analfabeto - mas também usava as leis literárias para agir em defesa de algum personagem que ele pode ter considerado injustiçado por algum autor, como em Sepé - o morubixaba rebelde (1964), em que ele utiliza um recurso literário, a intertextualidade, para recontar a história do líder missioneiro, como se tomasse as dores do índio, sendo que quem se assume como índio é o João do Adro, como em uma trova manuscrita em sua agenda pessoal: "Sou índio velho, arajano, /Um aporreado bagual, / Que não suporta tirano,/ Abotoador de buçal!” (JOÃO DO ADRO. In. FERNANDES BARBOSA, 1968).

Esse posicionamento do autor mostra que mesmo assinando como Fernandes Barbosa, no espaço particular de seu livro, como em Sepé - o morubixaba rebelde (1964) e outras obras, ele era solidário ao povo, nesse poema, inclusive, quase todo escrito em sextilhas, métrica popular, ele acaba não conseguindo conter o João do Adro que traz dentro dele, que se revela na estrutura da última parte da obra, e escrita em soneto destoando um pouco de todo o resto, e deixando sobressair o lado acusador e defensor do homem do povo que acusa diretamente o escritor Basílio da Gama, autor do reconhecido épico O Uraguai (1779) de "pelego nacional" 
que "desejando favores da corte, através do ministro Sebastião José de Carvalho, escreveu o poema 'O Uruguai', falseando, subalternamente a verdade histórica, em detrimento de Sepé Tiaraju” (FERNANDES BARBOSA, 1964, p. 83). Observa-se que a manifestação do poeta pode ser compreendida como uma representação que nos leva a refletir sobre as dificuldades de se fazer uma arte de negociação quando ainda existem alguns traumas a serem superados. Logo percebemos que ambos, o Fernandes Barbosa e João do Adro têm características semelhantes, ambos parecem não aceitar tão facilmente traição, principalmente quando vem daqueles que dominam os espaços e as leis, sejam políticas ou literárias. Ambos são solidários ao povo.

Já o Fernandes Barbosa, em seu livro Os Gato e o Remédio (1949) se assume como velho caboclo que passa horas matutando para encontrar uma forma de resolução para os problemas do Brasil, conforme em "A voz de um fuzil", do livro citado:

Às vezes passo horas a pensar, / Como um velho caboclo a matutar / $\mathrm{Na}$ crescente miséria do país. / E pensando interrogo os meus botões / Por que motivo as pragas dos ladrões / Não se podem cortar pela raiz? / Interrogando, volto a interrogar / Qual o melhor processo de acabar/ Com a corja maldita dos larápios? / Que tangendo esse povo como ovelha / Traz o lápis agudo atrás da orelha / Para alterar o preço dos cardápios? / E diante dos meus olhos cismarentos, / Que sonham com crepúsculos nevoentos, / Surge a imagem delgada de um fuzil, / A gritar para cinco mosquetões: / - O Brasil acaba com os ladrões, / Ou os ladrões acabam com o Brasil! / (FERNANDES BARBOSA, 1949, p. 08)

Em suas atuações literárias, nota-se que as referências identitárias do próprio "eu" se modificam, conforme os espaços em que se manifestam. Desde já, podemos perceber que o João do Adro é mais impulsivo, e não age de forma imediata na busca de solução para um problema, e às vezes pode chegar a ser extremista. Já o Fernandes Barbosa, emprega um esforço intelectual maior, e mesmo quando chega a ser extremista, o faz já medindo as causas e consequências, como num exercício de dizer e desdizer, recorrendo a vários recursos estilísticos, como a sátira, a ironia, a intertextualidade, metáforas, metonímias, entre outros recursos disponíveis no exercício criativo nesse espaço literário. Evidente que nos dois casos são representações muito bem arquitetadas e que podem ser entendidas dentro de um projeto literário mais amplo, resultado de toda uma dedicação à literatura e ao povo.

Em síntese, até aqui, podemos dizer que, o Jornal é um espaço público que ambos têm acesso. Tanto o João do Adro, o "eu-fictício" que representa o intelectual do povo, como o Fernandes Barbosa, o "eu-fictício" que representa uma classe trabalhadora, e que já ocupa as estruturas sociais. Diferente do espaço do Livro, que embora seja público, está limitado a um público mais restrito, mais próximo do espaço privado do autor. Isso revela até as dificuldades de um tipo de intelectual que emerge do povo e não consegue ser publicado como autor de livro, e quando é publicado em jornal tem seus textos possivelmente censurados e, até, modificados. 
Porém, apesar de, talvez por isso mesmo, o espaço de publicação do livro ser um espaço privilegiado, nele há também suas dificuldades e problemas a serem enfrentados e superados pelo sujeito que se posiciona e se ver diante de tomadas de posições, de poder de decisões, entre outros que abordaremos com mais afinco mais adiante, após definirmos o que caracterizamos como espaço privado, e como o autor se manifesta nesses espaços.

\section{ESPAÇO PRIVADO}

Quando falamos em espaços privados, a primeira coisa que vem em mente é o capital, no caso do livro, são os recursos financeiros que viabilizaram a publicação e circulação do livro. Embora atualmente o autor tem a opção de se auto publicar, desde que possua verbas para assim o fazer, nem sempre foi assim.

Fazendo uma breve e sucinta contextualização com a história do livro, no Brasil, podemos afirmar que as dificuldades vêm desde o período colonial, no século XVIII, em que o autor para ter uma obra publicada dependia de um mecenas, um rei ou alguém de confiança do rei, que visse a obra com bons olhos e a recomendasse para a publicação, como aconteceu com obras dos poetas do círculo pombalino, que foram apreciadas pelo Marquês de Pombal e publicadas pela tipografia da Universidade de Coimbra, como por exemplo O Desertor (1774), de Silva Alvarenga, e O Uruguai (1769), de Basílio da Gama, entre outras.

No século XIX, com o processo de industrialização e o surgimento de vários jornais, surgem os primeiros romances, cujos capítulos passam primeiro pelos jornais, e só depois de caírem nas graças dos leitores que foram publicados na versão em livro. Com o processo de independência do Brasil, não há mais a figura do mecenas e os artistas se veem com mais dificuldades de serem publicados.

No século XX, além das dificuldades financeiras, os artistas se deparam com as censuras às artes desde o Estado Novo, e a Ditadura militar. Alguns deles resistiram a esse controle excessivo, outros conseguiram driblar esses sistemas, e ainda conseguiram apoio de amigos para a publicação de suas obras, como foi o caso de Nilo Fernandes Barbosa.

Mas voltando à questão do sentido de espaço privado, é óbvio que ele não se limita apenas ao espaço reservado e representado pelo livro, sua significação vai mais além, e para entender um pouco melhor, partiremos do sentido mais básico e claro:

1. Que se privou de; desprovido. 2. Que não é público, ou não tem caráter público; particular. 3. Pessoal, íntimo. 4. Direito privado, conjunto de regras que regem as relações dos indivíduos entre si ou pessoas jurídicas do direito público, quando agem como particulares (LARROUSE, 2001, p. 800). 
Apesar de o livro ser um objeto que acreditamos ser, ou que deveria ser, público, quando ele se tornou privado, no sentido de proibido ou impedido, de alcançar um maior número de leitores, e ficou restrito há um número seleto e específico de leitores, e, de certo modo, no período em que foi publicado o livro foi privatizado. Ou seja, não foi tão público como deveria ser ou como seu autor desejaria que fosse. Nem sempre isso é culpa do autor, e é difícil precisar de quem é a culpa. Mas podemos deduzir que isso é consequência de todo um sistema, uma estrutura social que influenciou, e dificultou, o processo de publicação para os autores, e o acesso pelos leitores. Como estamos falando do século XX, sabemos que há uma série de dificuldades que o autor enfrentou de ambos os lados, seja do Estado, seja do mercado editorial.

Além da questão que gira em torno da privatização do livro, consideramos também para uma compreensão mais ampla quando falamos em espaço privado, os conteúdos veiculados sob forma literária nesses livros e até fora dele, considerando os vários poemas que foram, inclusive, privados de publicação e, por isso, permanecem inéditos, arquivados no Museu de Cachoeira do Sul-RS. Nota-se que os conteúdos, os temas, as motivações, que deram à luz a uma obra tão extensa, giram em torno de questões pessoais, particulares do autor. Ou seja, são poemas que partem da sua experiência de vida e de seu convívio social, político e cultural. E mesmo quando a inspiração surge do outro, pessoas, coisas, e questões exteriores do poe$\mathrm{ma}$, inevitavelmente, na obra literária prevaleceu a ótica do próprio autor que ao escrever, de algum modo se inscreve na própria escritura.

Apesar de os poemas também terem, mesmo que implícito e distanciado, o aspecto privado do autor, pois, revela a posição subjetiva de um "eu" atuando publicamente, e isso exige tipos de análises específicas que considerem os espaços em que tais poemas foram publicados. Pois, diferente dos poemas publicados em jornais, a publicação em livro redobra a exigência com as leis que regem as estruturas de uma obra literária. E isso exige uma postura diferenciada do autor, uma vez que o livro geralmente é considerado e reconhecido como um espaço, digamos, privilegiado.

\section{A) O PROCESSO DE AUTO PUBLICAÇÃo E A PRIVATIZAÇÃO DO LIVRO}

Em relação ao processo de publicação dessas obras, Nilo Fernandes Barbosa (1910-1988) conheceu na pele os desafios do escritor no século XX, como dificuldades para conseguir a publicação por uma editora, e/ou patrocínio para publicação, e/ou arcar com os próprios custos editoriais. Tais dificuldades se davam: ou por falta de recursos financeiros suficientes para sanar tais gastos, considerando a atividade de produção literária maior que aquilo que poeta podia bancar; ou por censura das obras pelas próprias editoras, motivo esse que se tornou mais intenso na época da ditadura militar. Diante dessa realidade, eis o resultado: apenas nove, dessas quatorze obras reunidas, foram impressas no formato de livro convencional, sejam por editoras, gráficas ou tipografias. Outras quatro foram editadas e tornadas públicas 
em versões datilografadas pelo próprio autor. De todas as obras, inclusive as datilografadas, o autor fazia várias versões as quais distribuía gratuitamente. Além dessas, foi encontrada uma grande quantidade de poemas esparsos, publicados em jornais, e tantos outros inéditos, alguns disponíveis no Jornal do Povo e outros, ainda guardados com familiares e amigos do poeta.

Para entender como se deu esse sistema de auto publicação é preciso uma análise da relação entre autor, obras e edições. Tal análise literária terá resultados mais eficazes se: atreladas a uma pesquisa histórico literária - com base em artigos e poemas publicados em jornais da época, originais, fontes primárias, cartas sobre a recepção das obras; e se considerar entrevistas de amigos e familiares da época.

As duas primeiras obras do poeta Frutinha Proibida (1938) e Minhas flores de jacarandá (1944) foram impressas na Tipografia Portela e os poemas desses livros tem um forte teor nacionalista, com sonetos e com versos livres cheios de imagens de nacionalismo, da musicalidade e sensualidade do nosso samba, ritmo e beleza, temática apreciada pelos modernistas. O início na vida pública corroborou para a consagração de uma vida de autoria literária. Em 1937 iniciou sua carreira de funcionário público na Prefeitura Municipal de Cachoeira do Sul e um ano depois, aos vinte oito anos de idade, dois anos após seu casamento, publicou seu primeiro livro de poesias intitulado Frutinha proibida (1938). Obra que reúne poemas da juventude do poeta, alguns escritos na adolescência, publicados na revista do colégio militar, outros escritos e publicados em jornais da cidade, alguns da época em que trabalhava como revisor. (OLIVEIRA, 2016, p. 74 - 78).

Até a publicação de Minhas Flores de Jacarandá (1944), muitos fatos aconteceram. Em 1939 foi diretor da Instrução Pública no governo Reinaldo Roesch, em 1941 passou a ser diretor da Instrução pública Municipal no governo Ciro da Cunha Carlos, em 1942 atuou como Secretário geral da União Central de Rizicultores, até que em 1944 tornou-se representante da lavoura orizícola de Cachoeira do Sul - no IRGA. Temos então um poeta já ativo e envolvido no cenário educacional e cultural de Cachoeira do Sul, e também na atividade agrícola. Nesse contexto, aos 34 anos de idade, o poeta torna público seu livro de poemas Minhas Flores de Jacarandá (1944), marcado pela tristeza e saudades da mãe já falecida (em 1936) e lembrada pelo poeta aos seus "vinte e nove desenganos", como versa. (OLIVEIRA, 2016, p. 78 - 81).

Em 1946 e em 1947 trabalhou como secretário municipal no governo Mario Godoy Ilha e no governo Liberato Salzano Vieira da Cunha, sucessivamente. Parece que o convívio social no cenário, com o passar dos anos, fez com que o poeta ficasse mais crítico e revoltado com a crise política que rondava o país. Tal convivência acabou, de certa forma, contaminando a criação literária do poeta que desenvolve um lado satírico e contestador. Em 1949, o poeta desfila entre os amigos um livro composto de poemas com um lirismo mais satírico, de forte crítica à situação política do Brasil e à crise financeira, ao endividamento, à corrupção política durante e posterior à crise econômica do "Estado Novo", certa descrença em relação aos políticos e às politicagens na Era Vargas. O livro, Os 'gatos' e o remédio (1949), publicado na Sociedade Gráfica, 
em Cachoeira do Sul, após analisado à luz das transformações do gênero épico, pode vir a ser classificado como um poema épico - cômico com grande teor satírico com fortes marcas da ironia. (OLIVEIRA, 2016, p. 81 - 84).

De 1952 a 1954 Fernandes Barbosa trabalhou como diretor da Biblioteca Pública de Cachoeira do Sul do governo Virgilino Jaime Zinn. Nesse mesmo ano, deixando seu lado satírico para o seu pseudônimo "João do Adro" e sem deixar de publicar suas sátiras nos jornais locais, o pseudônimo Fernandes Barbosa dá, ao universo literário, uma Carreirada que consiste em um longo poema regional escrito todo em 37 sextilhas e versos em redondilha maior, com rimas $\mathrm{AABCCB}$, métrica consagrada popularmente. No livro não consta informações sobre a editora, ao que indica trata-se de uma edição do autor. (OLIVEIRA, 2016, p. 84 - 86).

Em 1956 Fernandes Barbosa escreve poemas infantis que ele agrupa manualmente em um livrinho datilografado intitulado Figurinhas do Bazar. Foi um trabalho que não chegou a ser publicado em editoras, e a cujo exemplar está acessível no Museu Municipal Edyr Lima, em Cachoeira do Sul. Em 1958, Fernandes Barbosa repete a experiência de escrever para a criançada e faz circular entre elas um poema épico infantil intitulado Noite Feliz. (OLIVEIRA, 2016, p. 86 - 89).

Em 1959 a 1963 foi diretor da Biblioteca Pública de Cachoeira do Sul no governo Moacir da Cunha Roësing, durante toda sua vida pública e literária, o poeta sempre esteve em contato com as lendas, com a poesia, com os livros, em geral. Apaixonado pela lenda do negrinho do pastoreio, em 1959 o poeta agracia seus familiares e companheiros com um belo poema épico intitulado Súplica ao Negrinho do Pastoreio (1959), publicado pela Tipografia Santa Cruz, em Santa Cruz do Sul. Foi um livro muito apreciado pelos amigos, críticos e historiadores que the enviaram cartas tecendo elogios e agradecimentos pelo exemplar recebido. Essas cartas estão disponíveis no Museu Edyr Lima, em Cachoeira do Sul. Além dessas há outras cartas sobre outras obras do poeta, como Sepé - o morubixaba rebelde, Preto e Branco, Esboço de uma Época, por exemplo. Além de diversos artigos publicados em Jornal do Povo, Cachoeira do Sul, entre outros jornais de circulação local. (OLIVEIRA, 2016, p. 89-91).

Em 1960, o poeta publicou Cretino é quem toma de uma enxada, que segundo ele é: "outra sátira em sextilhas decassílabas, narrando a odisseia por qual passavam os rizicultores para conseguirem a assinatura de um contrato, junto à carteira de crédito do Banco do Brasil". (FERNANDES BARBOSA, 1981). Ao que parece, essa é uma das obras que não chegaram a ser impressa em gráficas, tipografias ou editoras. Há no museu de Cachoeira do Sul, uma versão manuscrita, organizada manualmente e amarrada em um fitilho pelo próprio poeta, como costumava fazer com todas suas obras antes de enviá-las para impressão.

Fernandes Barbosa, também foi chamado de "Poeta Contestador", devido às sátiras aguçadas e mordazes de seus versos críticos em relação à casta de políticos brasileiros, às mazelas sociais, à corrupção e a tantos outros assuntos que o afligia. Agindo sempre com ideias firmes e convicto de suas crenças, Fernandes não se intimidava na hora de dar o seu grito de protesto, chegando muitas vezes a ser penalizado por tamanha ousadia e audácia. Um 
exemplo disso foi quando escreveu o poema "O prefeito e os ovos", poema usado em defesa de um feirante que estava prestes a ir para a cadeia por ser acusado pelo fiscal de esconder os ovos em uma feira-livre e por quase ser condenado pelo prefeito. Esse poema lhe custou 30 dias de suspensão do serviço público, sem vencimentos. Em represália, o poeta publicou "Sargento, capitão, prefeito" acusando e criticando o prefeito de, mesmo sendo um "fulgurante analfabeto", conseguir progredir de sargento para o cargo de capitão e depois tornar-se prefeito. Esse fato teve a maior repercussão na cidade e foi comentado por Wilde Pacheco no Diário de notícias (1966):

Quando determinado prefeito de Cachoeira, há anos, praticou contra o colono ato que ao poeta pareceu arbitrariedade, saiu à liça. Mesmo sendo servidor municipal, publicou no Jornal do Povo, tradicional órgão local, violento poema em que glosava e combatia sua atitude. Quando viu ameaçado de suspenção, voltou à carga. Mais violento. Não teve, então, papas na língua. O prefeito foi atacado de todo jeito, tachado de ignorante e incapaz, além de muitas coisas mais. Foi lançado ao ridículo pela pena virulenta do poeta... (PACHECO, 1966).

Poemas como estes, com quais ele presenteou grande casta de políticos e padres, encontram-se publicados em vários livros satíricos do poeta e nas várias folhas do Jornal do Povo, assinados por João do Adro. Fernandes Barbosa também era conhecido e respeitado por agir sempre em defesa dos menos favorecidos e dos injustiçados. Apesar de não ter formação em direito, atuou como rábula. Por esse motivo era sempre requisitado para defender os mais pobres e em suas defesas, muitas vezes, escrevia poemas no exercício da advocacia. Esses poemas eram publicados no Jornal do Povo.

Apesar de atuar como advogado, o poeta era reconhecido como um homem das letras, e se transitava pelo caminho das leis, era para dar voz, através da arte àqueles que, para ele, eram silenciados socialmente. Segundo o filho do poeta, Danton Fernandes Barbosa, o pai chegava a ganhar causas apresentando seus poemas. Já sua filha Ana Maria Barbosa lembra-se de ouvir a mãe resmungar temerosa "Não sei como não mandam prender ele, pois não tinha papas na língua e publicava coisas terríveis contra o que via na época” (BARBOSA In. OLIVEIRA, 2016, p.178).

Quatro anos depois de tornar público seu poema Cretino é quem toma de uma enxada, e com o mesmo espírito satírico, mas temperado com regionalismo e simbolismo nativo, ele publicou seu Sepé - o morubixaba rebelde (1964), pela tipografia Santo Antonio - Pão dos Pobres. Não foi fácil descobrir o ano de publicação dessa obra, pois diferentes de outras, nela não havia data em que foi publicada. A resposta veio depois de pesquisar no arquivo histórico do Jornal do Povo que trazia matérias. Não se sabe se tal ocultação foi por vontade do autor, editora e o motivo. Coincidentemente, ou não, foi publicada no ano que dá início a Ditadura Militar no Brasil, trazendo algumas marcas desta, ao ponto de poder ser lida por alegoria. 
Ana Rita, a filha do poeta, em entrevista comenta que Sepé - o morubixaba rebelde foi o trabalho mais difícil e demorado que seu pai concebeu. E que o poema foi um de seus livros mais aclamado por críticos literários, como Saint Pastous, Manoelito de Ornelas, Walter Spalding e Nelson Werneck Sodré e também recebeu muitas manifestações de elogios de amigos de Santa Maria, Rio de Janeiro, Curitiba e Porto Alegre que lhe chegavam às mãos através de cartas, telegramas e cartões.

Nesse mesmo ano, 1964, em que Fernandes Barbosa publicou o Sepé - o morubixaba rebelde, o poeta Faride Germano Machado comenta, em sua "Carta ao Poeta Fernandes Barbosa", publicado no Jornal do Povo, sobre um livro em andamento intitulado Procissão de sonhos e de saudade, onde o Fernandes Barbosa publicaria, entre outros poemas, o soneto "Ana Maria" que ele presenteou a sua filha caçula em seus quinze anos. No entanto, parece que o livro não chegou a ser publicado. Talvez esse fosse o seu último livro, aquele em que, segundo Faride Machado (1964), "todos desejariam ler e aplaudir" (OLIVEIRA, 2016, p. 97).

Em 1965, Fernandes Barbosa torna-se o fundador e animador da Sociedade Avícola Cachoeirense, concretizando em 1970 a construção da sede própria da entidade. Durante os anos de 1978 a 1982, foi diretor da Biblioteca Pública de Cachoeira do Sul no governo Júlio César Caspani. Em 1978, o poeta publica um livreto, ou cartilha, intitulado Para aonde marcha o Brasil? (OLIVEIRA, 2016, p. 97).

E em 1983 foi diretor da Biblioteca Pública de Cachoeira do Sul no governo Ivo Renê Pinto Garske. Nesse mesmo ano recebeu uma placa de reconhecimento da Secretaria Municipal de Cultura pelo relevante trabalho que desempenhou na Biblioteca Pública Municipal "Dr. João Minssen”. Em 1984, Fernandes Barbosa já com seus 74 anos de idade escreve Tradição Relambória, que, segundo o poeta, não o fez "com propósito de publicá-lo, mas, tão somente, como simples desabafo da alma inconformada". O livro foi dedicado à memória de seu tio-avô Major João Cezimbra Jacques, pioneiro no movimento tradicionalista. Nele, o poeta defende o tradicionalismo e lamenta a deturpação dos costumes gaúchos. (OLIVEIRA, 2016, p. 98).

Depois de dedicar quarenta anos de sua vida ao serviço público de Cacheiras do Sul-RS, Fernandes Barbosa aposentou-se em 1984. Em 21 de Janeiro de 1986, o Jornal do Povo notícia que o Poeta Fernandes Barbosa estava escrevendo um novo livro intitulado A Revolta da Chibata, porém, até o momento, não é conhecido pelos familiares e amigos, com quais tive contato durante a pesquisa, nenhum livro com o referido título, no entanto pela temática histórica e pelo ano, 1986, é provável que o jornal fizera referência ao livro Preto e Branco. Se for o caso, como aconteceu com outras obras, o poeta pode ter mudado o título do livro antes de publicá-lo, daí a publicação constaria outro nome. (OLIVEIRA, 2016, p. 100 - 102).

Nesse ano, em 1986, dois anos que antecederam sua morte, Fernandes Barbosa publica Preto e branco, pela editora Gráfica Metrópole S.A. Como as outras obras do poeta, este livro recebeu grandes elogios pelos leitores. Nele, o poeta aborda novamente a lendária história do negrinho do pastoreio, e traz também a história do negrinho João Câmara, da Revolta da 
Chibata. O livro é dividido em quatro partes. Na primeira, o poeta inicia abordando a lenda do negrinho do pastoreio, focando assim no plano maravilhoso. Na segunda parte o poema aborda o plano histórico, ao versar sobre o heroísmo do sujeito histórico o negro João Câmara, da Revolta da Chibata. Nesse mesmo ano em que escreve Preto e branco, ainda em 1986, ele também lançou Trovas ao vento aos amigos e familiares. O livrinho foi editado manualmente pelo autor e foi distribuído ao público bem restrito, nessa versão manuscrita. (OLIVEIRA, 2016, p. 103).

Em 1987, um ano antes de sua morte, Fernandes Barbosa publicou seu último livro de poesias, o Esbôço de uma época, que foi mais uma manifestação do lado satírico do poeta inconformado com a corrupção do país e impotente como cria ser o estado de espírito do cidadão brasileiro, naquela época. O livro esboça, em poesias satíricas contestadoras, uma época marcada pela corrupção política, e pelas mazelas sociais que afligiam o Brasil na década de 80. Mesmo passado quase 30 anos da composição destes versos, seus protestos parecem ecoar na atualidade. Um dos sonetos que esboçam essa época e que, infelizmente, pode ser repetido geração a geração é o "Estribilho" de seu grito de protesto. (OLIVEIRA, 2016, p. 10 -106).

Conforme apresentado, Nilo Fernandes Barbosa (1910-1988) travou um árduo caminho como escritor. Das quatorze obras escritas, nove chegaram a ser impressas em editoras, gráficas e tipografias. Em entrevista, o amigo Mildo Leo Fenner que conviveu com ele enquanto trabalhou no Jornal do Povo, revela que Fernandes Barbosa, enquanto

escrevia para o Jornal do Povo, fazia seus livros, em tiragens reduzidas, em torno de 100 exemplares, e os distribuía aos amigos. Não queria lucros. Apenas pretendia dar o seu recado, em forma de poesias. Ele escrevia muito, há centenas de poesias publicadas ao longo dos anos no Jornal do Povo. Guardei algumas comigo. (FENNER In. OLIVEIRA, 2016, 188).

As obras que, pelos motivos já aqui mencionados, ele não conseguiu imprimir na versão convencional de livro, mas fez chegar a um público restrito através de edições manuais e/ou datilografadas.

\section{ESPAÇOS PÚBLICOS E PRIVADOS NO IMAGINÁRIO LÍRICO}

O poeta estabelece uma relação metonímica com as mãos, que inclusive foi fonte de inspiração em três de seus poemas homônimos. Vejamos o soneto "mãos" publicado em seu primeiro livro Frutinha Proibida (1938):

Mãos que com meiguice e arte andam tramando, / A teia mais delicada dessas teias, / Onde os corações vão se enredando, / Ouvindo a voz maviosa de sereias... / Mãos que a caridade andam espalhando... / Mãos que vivem do meu beijo alheias, / E que um famoso artista fez 
juntando, / As espumas do mar sobre as areias... / Mãos que lembram a graça das ofélias... / E são irmãs, na terra, das camélias... / Mãos que venero com orgulho imenso... / Eu quero numa tarde, assim, de outono, / Quando chegar o derradeiro sono, / Delas levar o derradeiro lenço! /. (FERNANDES BARBOSA, 1938, p. 9).

A relação metonímica que o poeta estabelece, tomando mãos para representar o próprio poeta em nesse espaço literário, quando ele utiliza as duas mãos na criação, a esquerda e a direita, que no sentido ideológico que o poeta emprega, representam seus dois pseudônimos: Fernandes Barbosa, o Girondino; e o João do Adro, o Jacobino. Pois são através de ambos que "tramam" sua arte literária, a teia mais delicada de todas. Uma teia cheia de múltiplos sentidos e significados, em que ele busca enveredar nas trilhas do amor, do romantismo.

As mãos metaforizadas na própria literatura, tecem num espaço silencioso do poeta, um espaço que é só dele. Era esse silêncio das madrugadas que o poeta buscava para escrever quando se trancava em seu escritório e passava horas lá escrevendo sua "coroa de sonho e martírio", pois é verdade que a poesia às vezes vinha do inconsciente, do imaginário, mas, às vezes, também vinha de uma história de sofrimento. E quando calhava de vir dos dois, temos o épico, gênero muito cultivado pelo poeta nesse espaço solidário e solitário.

Segundo Blanchot (2011), o artista encontra nas artes uma forma de sair da seriedade da vida como um meio de se proteger do mundo onde ele encontra dificuldades para agir e com isso ele se desloca para um mundo irreal onde ele tem liberdade para agir, sem, no entanto, renunciar o conforto do mundo - que eu diria até desconforto, também - e as aparentes facilidades de agir fora do tempo. Passando, muitas vezes, a impressão de fragilidade e de um vingador de seus fracassos da e na sociedade (BLANCHOT, 2011, p. 48-49). Daí a necessidade de escrever para expurgar esse tormento inconsciente e consciente que o afligia e, às vezes, fazia de sua escrita uma prece, em que unindo as duas mãos, o eu-lírico invoca ao Senhor, ao criador.

Olhai, Senhor, as mãos escalavradas, / Porém sublimes quanto às mais preclaras, / Dos que, lavrando pelas madrugadas, / Ao sol semeiam das manhãs mais claras! / Olhai, Senhor, as pobres mãos pisadas, / E que jamais souberam ser avaras, / Dos que transformam terras arroteadas, / Nas telas paisagistas das searas! / Vós que fostes, também, um semeador, / Protegei cada humilde plantador: / Herói sem nome na maior batalha! / E abençoai seu rancho - é reza minha! / Onde o labor de sol a sol se aninha / E o malogro de safras se agasalha! / (FERNANDES BARBOSA, ?')

\footnotetext{
${ }_{2}^{2}$ Poema inédito, de uma Antologia de poemas organizada por Ana Rita Fernandes Barbosa, filha do poeta, disponível para consulta no Museu Municipal de Cachoeira do Sul - RS. Esse poema também consta em um livrinho ou caderno datiloscrito / manuscrito intitulado "Sonetos do cotidiano", do meu arquivo pessoal, doado por Ana Maria Fernandes Barbosa Carlin.
} 
$\mathrm{Na}$ "Prece" o eu-lírico se põe na posição de um trabalhador, que invoca ao "Senhor", que seria o criador, o poeta que olhe por aqueles que são trabalhadores, semeadores, como ele. Na primeira estrofe, ele já não vê as mãos tão delicadas de seus primeiros versos da juventude, mas as mãos "escalavradas", marcadas pelos golpes duros da vida.

No último verso do poema, o sentimento do eu-lírico é de frustração, de insucesso, por não ter ido avante, por, talvez, sentir que não colhera os frutos que desejaria ter colhido em suas safras literárias. Assim, a luva também serve de agasalho para esse "malogro de safras", pois como ele mesmo versa em seu poema "Grilo com mania de cigarra", "nem flores do campo conquistou". Essa luva pode ser considerada como o escudo de proteção do poeta. Assim sendo, tal como afirma Blanchot (2011), "o artista não se protege somente do mundo, mas da exigência que o atrai para fora do mundo" (BLANCHOT, 2011, p. 49).

Segundo Blanchot (2011), “a arte não é religião” (BLANCHOT, 2011, p.49), e a literatura não tem uma função religiosa, mas, de algum modo, é a ela que o artista se apega, tal como um religioso, para sair de si, do mundo, principalmente em tempos de guerras e crises da humanidade. É na literatura que o artista das letras se enterra tal como o crente em sua religião. E desse escape espiritual, buscado no ato de escrever, podem brotar as mais belas árvores para compor uma paisagem romântica idealizada, ou podem ser cavadas cacimbas de onde fluíram correntes literárias que desaguam num rio, no Nilo Fernandes. Ou seja, que expresse o próprio estado de espírito do poeta diante do mundo.

Nesse espaço literário, o poeta às vezes buscava a inspiração que vinha do chão, na calçada, desse lugar frio e marcado pelas pegadas de almas torturadas pelas ditaduras e pelo sofrimento da vida moderna, conforme revela o eu-lírico de "Desfile das almas torturadas", um soneto cheio de drama e feito para apresentar a declamadora dramática ao povo de Cachoeira do Sul:

Almas aflitas, almas torturadas, / Que trazem sempre os corações sangrando; / Almas que se asfixiam, sufocadas, /Num turbilhão de lágrimas rolando... / Almas que vão ao longo das calçadas, / De bôcas retorcidas, soluçando, / Porque sentem nas carnes, machucadas, / O látego da vida fustigando / Almas que têm Vesúvios dentro dalma / E que se agitam, trêmulas, sem calma / Vão agora, nesta sala, desfilar... / Nos versos declamados por Mafalda / - Esta flor tropical, esta esmeralda - / Que eu venho, prazeroso, apresentar. (FERNANDES BARBOSA, sem data) . $^{3}$

As almas torturadas refletem o drama da verdade sobre a dor humana quando representada nas artes. Verdade semelhante a qual se referia Blanchot (2011) ao falar da verdade

${ }^{3} \mathrm{O}$ soneto faz parte de documentos datiloscritos e manuscritos do autor que está sob os cuidados de sua filha Ana Rita Fernandes Barbosa, em Cachoeira do Sul - RS. Muitos desses arquivos, estão sem data. Recebi cópias de alguns desses poemas, dentre eles encontra-se "Desfile das almas torturadas". 
solitária do artista que o sufoca numa separação incompreensível (BLANCHOT, 2011, p. 50). Algumas vezes incompreensível, talvez, porque separar-se do mundo e agir "fora dele" é uma tortura, é como arrancar a alma do corpo para fazê-la existir na arte.

No poema acima, a imagem criada pelas "bocas retorcidas, soluçando" expressam a sensação inconsciente do poeta que parece vivenciar o mal-estar social que se cruza no espaço literário do poeta e revela sua percepção de vida na literatura. Às vezes, a calçada, o chão, precisa ser cavadas pelas mãos do poeta abrindo cacimbas de onde fluíam rios de poesias, conforme ele versa em "meu verso": "Meu verso flui sem batucar de dedos,/ Pois, da cadência o ouvido se encarrega... / Teço rendas de bildro dos enredos / E o verso barco, no macio, navega. (...) / E todos brotam, espontaneamente, / Que nem água subtérrea de vertente, / Que através das cacimbas vem do chão!" (JOÃO DO ADRO, 1983).

A inspiração vinha do chão, como no poema "Grampo discreto" que, conforme explica em entrevista o amigo Sérgio Duarte, conta a história de um grampo que uma moça descuidada deixou cair na calçada e o poeta, ao observar o amigo pegar o grampo, escreveu seu poema que, na ocasião, foi feito para ser a letra de um samba que não chegou a conhecer a melodia. (DUARTE In. OLIVEIRA, 2016, p.192). Esse lugar ora chamado de chão, ora calçada, ora calçadão, era o espaço de criação do poeta, nele escrevia e se inscrevia. Esse calçadão era a sua literatura, que para muitos era como uma "velha praça" mas que o poeta fazia questão de cuidar e preservar o seu lirismo, mantendo a paisagem com as flores do romantismo e as imagens do simbolismo. Essa praça, lugar público, era o lugar errante do eu-lírico onde vagava em busca de inspiração, lugar que preserva a tradição. Comparando lugares, podemos associar o Galpão ao espaço privado e a velha praça ao espaço público, e o entre lugar desses espaços seria o chão, a calçada ou calçadão. É nesse entre lugar que se dá a realização de sua obra, conforme ele revela na trova: "Minha trova - pobre trova! / Que à calçada escrevo a giz, / Chuva apaga o que ela prova, / Vento leva o que ela diz!...”. (FERNANDES BARBOSA, 1986).

Nilo Fernandes parece crer que a Literatura pode algo, e é na angústia dessa crença que ele vive e que sua obra se realiza, mas no final ele, frustrado, acaba descobrindo à duras penas que nada pode, nada prova. Embora resida num espaço de poder, uma vez que é linguagem, o poeta não escreve com intenção de provar. Desde o princípio ao fim, sua Literatura, mesmo quando ela se configura como arquivo ou escritura, e com isso revele seu poder de dizer. $\mathrm{O}$ que ela prova é apagado pela chuva, pela vida, uma vez que é ficção. O que ela diz é levado pelo vento, e seu destino e incerto, pode chegar a nenhum lugar, ou pode voar aos quatro cantos do mundo.

\section{CONSIDERAÇÕES FINAIS}

Devido a evidente contribuição literária deixada pelo autor, é notável que suas obras necessitam de um trabalho de edição, tendo em vista que: as primeiras edições das obras 
Frutinha proibida (1938), Minhas flores de Jacarandá (1944), Os 'gatos' e o remédio (1949), Carreirada (1954), Súplica ao Negrinho do Pastoreio (1959), Para aonde marcha o Brasil? (1978) encontram-se esgotadas; Preto e branco (1986); Esbôço de uma época (1987), Sepé-o morubixaba rebelde (1964), encontram-se apenas alguns raros exemplares; Figurinhas do Bazar (1956), Noite Feliz (1958), Cretino é quem toma de uma enxada (1960), Tradição Relambória (1984), Trovas ao vento (1986), encontram-se disponíveis nas versões originais encontradas em museus, familiares e amigos.

Conclui-se, então, que Nilo Fernandes Barbosa (1910-1988) figura um exemplo de autor que, muitas das vezes, e na maioria de suas obras, atuou como editor de suas próprias obras. Demonstrando não apenas vocação para o trabalho de escritor, mas, também, conhecimento no processo editorial. No campo editorial, tal atuação demonstra de um lado as dificuldades de escrever e publicar num período conturbado para o Brasil e para a literatura brasileira, por outro lado foi um exercício de resistência e existência literária, pois se não fosse esse esforço, talvez suas obras não teriam resistido até os dias atuais.

A obra de Nilo Fernandes se realiza numa dimensão espacial de um "não lugar", que não significa ausência de lugar, mas equivale dizer que não se limita a um lugar fixo, pois trata-se de uma literatura que se desloca. Ora dialoga com a tradição parnasiana, ora incorpora as contradições barrocas, ora é paisagem romântica, ora é esboço de extremo realismo, ora pensa com a ideologia francesa, ora contesta problemas brasileiros, ora é Fernandes Barbosa, ora é João do Adro... Ora é tudo isso ao mesmo tempo.

Daí surge a questão: como estar em mais de um lugar ao mesmo tempo? Só assumindo uma posição de "não lugar", de entre lugar. Só assim é possível se deslocar. Pois esse deslocamento a todos esses lugares é possível justamente por não estar em lugar nenhum, no entre lugar, na fronteira, onde o acesso aos lugares é possível, onde as culturas dialogam. Só estando na fronteira é que é possível ir além dela, e é por isso que a literatura de Nilo Fernandes não impõe e não se impõe fronteiras.

\section{REFERÊNCIAS}

OBRAS ORIGINAIS DO AUTOR / DOCUMENTOS LITERÁRIOS IMPRESSOS COM ANOTAÇÕES MANUSCRITAS

FERNANDES BARBOSA, N. Frutinha Proibida.1.ed. Cachoeira do Sul-RS: Tipografia Portela, 1938.

FERNANDES BARBOSA, N. Minhas Flores de Jacarandá. 1.ed. Tipografia Portela, 1944.

FERNANDES BARBOSA, N. Os “Gatos" e o "remédio". 1.ed.Cachoeira do Sul-RS: Sociedade Gráfica LTDA, 1949.

FERNANDES BARBOSA, N. Súplica ao Negrinho do Pastoreio. 1.ed. Santa Cruz-RS: Tipografia Santa Cruz, 1959. 
FERNANDES BARBOSA, N. Sepé, o morubixaba rebelde. 1.ed. Porto Alegre - RS: Tipografia Santo Antônio - Pão dos pobres, 1964.

FERnANDes BARbosa, N. Pelo mesmo caminho.... In. Para Aonde Marcha o Brasil? 1.ed. Rio Grande do Sul: Gráfica Jacuí LTDA. 1978.

FERNANDES BARBOSA, N. Preto e Branco. 1.ed. Rio Grande do Sul: Editora Gráfica Metrópole S.A., 1986.

FERNANDES BARBOSA, N. Esboço de uma época. 1.ed. (sem nome da editora e local de publicação). 1987.

OBRAS ORIGINAIS DO AUTOR / DOCUMENTOS LITERÁRIOS MANUSCRITOS E DATILOSCRITOS

FERNANDES BARBOSA, N. Noite Feliz. Original da primeira e única edição. Datiloscrito. In. Documentos do autor. Cachoeira do Sul- RS: Museu Edyr Lima, 1958.

FERNANDES BARBOSA, N. Cretino é quem toma de uma enxada. Original da primeira e única edição, capa manuscrita, miolo datiloscrito. In. Documentos do autor. Cachoeira do Sul- RS: Museu Edyr Lima, 1960a.

FERNANDES BARBOSA, N. Cretino é quem toma de uma enxada. Original do autor, datiloscrita. In. Documentos do autor. Cachoeira do Sul- RS: Museu Edyr Lima, 1960b.

FERNANDES BARBOSA, N. XLII. In. Trovas ao vento. Original do autor, capa manuscrita, miolo datiloscrito. Meu arquivo pessoal. Doação da família. 1986.

FERNANDES BARBOSA, N. Esboço de uma época. Original do autor, capa dura, miolo datiloscrito, com riscos, correções e um soneto manuscritos. Meu arquivo pessoal. Doação da família. 1986.

FERNANDES BARBOSA, N. Bandeira do divino. Original do autor, datiloscrito. In. Documentos do autor. Cachoeira do Sul- RS: Museu Edyr Lima, (Sem data).

FERNANDES BARBOSA, N. “Agradecimento" e "Prece”. In. Sonetos do Cotidiano. Antologia de sonetos. Original do autor, capa manuscrita, miolo datiloscrito. Meu arquivo pessoal. Doação de Ana Maria, filha caçula. (Sem data).

FERNANDES BARBOSA, N. "Prece”. In. Antologia de poemas. Original do autor. Organizado por Ana Rita Fernandes Barbosa. Disponível no Museu Municipal de Cachoeira do Sul - RS, (sem data).

FERNANDES BARBOSA, N. "Solidariedade”. In. Poemas manuscritos. In. Agenda pessoal do autor do ano de 1968 / data provável.

FERNANDES BARBOSA, N. "Desfile das almas torturadas”. In. Documentos pessoais do autor. Sob os cuidados da filha Ana Rita Fernandes Barbosa. Datiloscrito, manuscrito e autografado. Cachoeira do Sul-RS, (sem data). 
JOÃO DO ADRO. "Olimpíada política". In. Jornal do Povo. Cachoeira do Sul - Rio Grande do Sul, (?). Recortes de Jornais digitalizados em pdf. Meu arquivo pessoal. Doação de Mildo Léo Fenner em 2015.

JOÃO DO ADRO. “Plágio”. In. Jornal do Povo. Cachoeira do Sul - Rio Grande do Sul, (1934). Recortes de Jornais digitalizados em pdf. Meu arquivo pessoal. Doação de Mildo Léo Fenner em 2015.

\section{DISSERTAÇÃO DE MESTRADO}

OLIVEIRA, E. S. O herói Sepéem duas versões: O Uraguai e Sepé - o morubixaba rebelde. Dissertação de Mestrado. São Cristóvão-SE: Universidade Federal de Sergipe, 2016.

BIBLIOGRAFIA TÉCNICA-TEÓRICA

BLANCHOT, M. O espaço literário. Tradução de Álvaro Cabral. Rio de Janeiro: Rocco, 2011.

BRANDÃO, L. A. Teorias do espaço literário. São Paulo: Perspectiva, 2013.

CANDIDO, A. Estudo analítico do poema. 3.ed. São Paulo: Humanitas, 1996.

CANDIDO, A. Noções de análise histórico-literária. São Paulo: Humanitas, 2005.

LARROUSE, Ática. Dicionário da Língua Portuguesa. Paris: Larrouse / São Paulo: Ática, 2001. ARTIGOS DE JORNAIS

AZEVEDO JR., J. L. B. Aplausos a um poeta. In: Jornal do Povo. Cachoeira do Sul - Rio Grande do Sul, 1964.

FERNANDES BARBOSA, N. Modernismo é um retrato do túnel: só se enxerga o oco. In: Jornal do Povo, Cachoeira do Sul - Rio Grande do Sul,1981.

GAMA DE BEM, B. Letras da cidade em 1964. In: Jornal do Povo. Cachoeira do Sul - Rio Grande do Sul, 1965.

MACHADO, F. G. Carta ao poeta Fernandes Barbosa. In: Jornal do Povo. Cachoeira do Sul Rio Grande do Sul, (?).

SARAIVA DE ALMEIDA, N. S. E morrera Fernandes Barbosa! In: Jornal do Povo. Cachoeira do Sul - Rio Grande do Sul, 1988.

Recebido para publicação em 19 dez. 2018. Aceito para publicação em 30 set. 2019. 